Article

\title{
Cobalt(II) Terpyridin-4'-yl Nitroxide Complex as an Exchange-Coupled Spin-Crossover Material
}

\author{
Akihiro Ondo and Takayuki Ishida * (ID \\ Department of Engineering Science, The University of Electro-Communications, Chofu, Tokyo 182-8585, Japan; \\ ondo@ttf.pc.uec.ac.jp \\ * Correspondence: takayuki.ishida@uec.ac.jp; Tel.: +81-42-443-5490; Fax: +81-42-443-5501
}

Received: 2 March 2018; Accepted: 29 March 2018; Published: 2 April 2018

\begin{abstract}
Spin-crossover (SCO) was studied in $\left[\mathrm{Co}(\mathrm{L})_{2}\right]\left(\mathrm{CF}_{3} \mathrm{SO}_{3}\right)_{2}$, where L

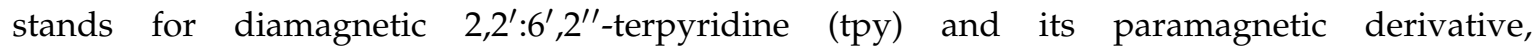
$4^{\prime}$-\{4-tert-butyl(N-oxy)aminophenyl\}-substituted tpy (tpyphNO). The X-ray crystallographic analysis clarified the Co-N bond length change $(\Delta d)$ in high- and low-temperature structures; $\Delta d_{\text {central }}$ $=0.12$ and $\Delta d_{\text {distal }}=0.05 \AA$ between 90 and $400 \mathrm{~K}$ for $\mathrm{L}=$ tpy and $\Delta d_{\text {central }}=0.11$ and $\Delta d_{\text {distal }}=0.06 \AA$ between 90 and $300 \mathrm{~K}$ for $\mathrm{L}=$ tpyphNO. The low- and high-temperature structures can be assigned to approximate low- and high-spin states, respectively. The magnetic susceptibility measurements revealed that the $\chi_{\mathrm{m}} T$ value of $\left[\mathrm{Co}(\mathrm{tpyphNO})_{2}\right]\left(\mathrm{CF}_{3} \mathrm{SO}_{3}\right)_{2}$ had a bias from that of $\left[\mathrm{Co}(\mathrm{tpy})_{2}\right]\left(\mathrm{CF}_{3} \mathrm{SO}_{3}\right)_{2}$ by the contribution of the two radical spins. The tpy compound showed a gradual SCO around $260 \mathrm{~K}$ and on cooling the $\chi_{\mathrm{m}} T$ value displayed a plateau down to $2 \mathrm{~K}$. On the other hand, the tpyphNO compound showed a relatively abrupt SCO at ca. $140 \mathrm{~K}$ together with a second decrease of the $\chi_{\mathrm{m}} T$ value on further cooling below ca. $20 \mathrm{~K}$. From the second decrease, Co-nitroxide exchange coupling was characterized as antiferromagnetic with $2 J_{\mathrm{Co}-\mathrm{rad}} / k_{\mathrm{B}}=-3.00(6) \mathrm{K}$ in the spin-Hamiltonian $H=-2 J_{\text {Co-rad }}\left(S_{\mathrm{Co}} \cdot S_{\text {rad1 }}+S_{\mathrm{Co}} \cdot S_{\text {rad2 }}\right)$. The magnetic moment apparently switches double-stepwise as $1 \mu_{\mathrm{B}} \rightleftarrows 3 \mu_{\mathrm{B}} \rightleftarrows 5 \mu_{\mathrm{B}}$ by temperature stimulus.
\end{abstract}

Keywords: spin crossover; spin transition; cobalt(II) ion; paramagnetic ligand; aminoxyl; switch

\section{Introduction}

Spin crossover (SCO) is a reversible transition between low-spin (LS) and high-spin (HS) states by external stimuli like heat, light, pressure, or magnetic field [1-3]. A number of materials are studied toward application in sensors [4]. Much attention has been paid to develop multifunctional SCO materials; for example, mesophase or liquid crystal properties [5-7] and magnetic exchange coupling [8,9]. Iron(II) $\left(3 \mathrm{~d}^{6}\right)$ coordination compounds are the most developed materials among various SCO complexes [10-13], because SCO occurs between $S=0$ dia- and $S=2$ paramagnetic states [14], drastically exhibiting magnetic and chromic changes. However, if one develops SCO materials having exchange coupling from an adjacent paramagnetic center, iron(II) compounds are unsuitable. In this line, cobalt(II) $\left(3 \mathrm{~d}^{7}\right)$ SCO behavior between $S=1 / 2$ and $S=3 / 2$ states are promising because the LS state is still paramagnetic (Scheme 1a). The entropy and geometry changes in cobalt(II) SCO compounds are less pronounced than those of iron(II) and iron(III) ones and it generally leads to a gradual SCO profile as a function of temperature [15-18]. A possible scenario of exchange-coupled SCO materials involves multi-step magnetic property jumps as a function of temperature. Namely, in the $\chi_{\mathrm{m}} T$ versus $T$ profile, a low-spin region has an additional spin-equilibrium regulated by magnetic exchange coupling. When a paramagnetic ligand (L) with $S_{\mathrm{rad}}=1 / 2$ is available, a $\mathrm{Co}^{2+}(\mathrm{LS}) / \mathrm{L}=1 / 1$ compound would show a singlet-triplet equilibrium, or a $\mathrm{Co}^{2+}(\mathrm{LS}) / \mathrm{L}=1 / 2$ compound a doublet-quartet equilibrium. 


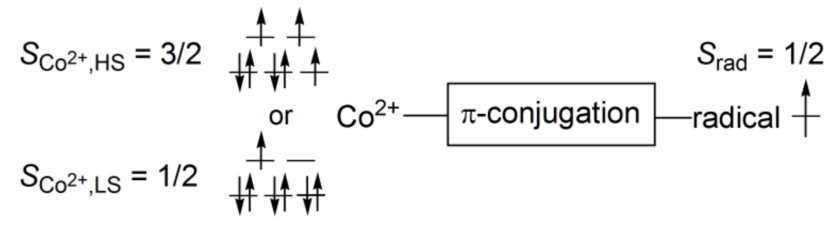

(a)

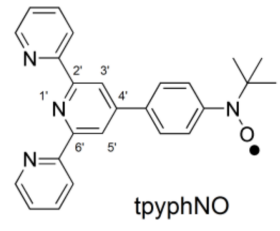

(b)

Scheme 1. (a) Schematic drawing of proposal for exchange-coupled spin-crossover materials; (b) Structural formula of tpyphNO.

The $2,2^{\prime}: 6^{\prime}, 2^{\prime \prime}$-terpyridine (tpy) ligands are popular to the cobalt(II) SCO materials [19-22]; for example, $\left[\mathrm{Co}(\mathrm{tpy})_{2}\right]\left(\mathrm{BF}_{4}\right)_{2}$ has been reported to exhibit $\mathrm{SCO}$ at $270 \mathrm{~K}[19]$ and $\left[\mathrm{Co}(\mathrm{tpy})_{2}\right]\left(\mathrm{ClO}_{4}\right)_{2} \cdot 0.5 \mathrm{H}_{2} \mathrm{O}$ displayed SCO at $180 \mathrm{~K}$ [20]. There have been a number of reports on the valence tautomerism in cobalt(II)-radical coordination systems [23,24]. Various photomagnets have been developed from heterospin systems including prussian blue analogues $[25,26]$. Such charge transfer mechanism also works in cobalt(II) spin-crossover materials carrying a directly coordinated nitroxide ligand [8,9], often disturbing the analysis of exchange interaction. Thus, our hypothesis is as follows: the organic paramagnetic center should be remote from the SCO center. A ligand $\pi$-electron system is indispensable to maintain appreciable exchange coupling (Scheme 1a). As for a paramagnetic substituent, tert-butyl phenyl nitroxide radicals are sufficiently persistent under ambient conditions [27,28]. Therefore, we designed a novel paramagnetic ligand based on tpy, $4^{\prime}$-\{4-tert-butyl( $N$-oxy)aminophenyl $\}-2,2^{\prime}: 6^{\prime}, 2^{\prime \prime}$-terpyridine (tpyphNO) (Scheme $1 \mathrm{~b}$ ). Its cobalt(II) complexes would be a target to realize the present project.

\section{Materials and Methods}

\subsection{Materials}

The ligands tpy and $4^{\prime}$-bromo- $2,2^{\prime}: 6^{\prime}, 2^{\prime \prime}$-terpyridine (Br-tpy) are commercially available. The latter was subjected to the preparation of tpyphNO (Scheme 2), as follows. The counterpart 4-(N-tert-butyl-O-tert-butyldimethylsilylhydroxylamino)phenyl boronic acid (TBDMS-BA) was prepared according to the literature method [29].

(a)

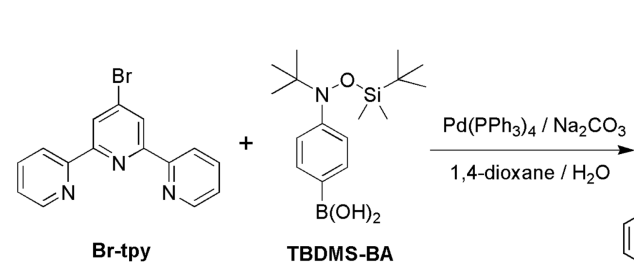

Br-tpy

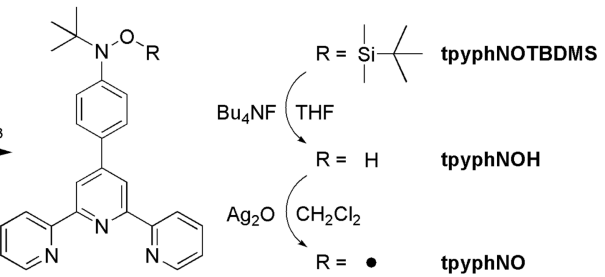

(b)
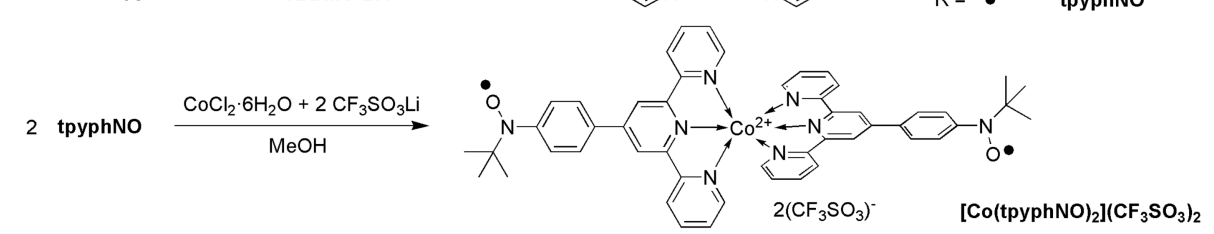

Scheme 2. Synthetic routes of (a) tpyphNO and (b) $\left[\mathrm{Co}(\text { tpyphNO})_{2}\right]\left(\mathrm{CF}_{3} \mathrm{SO}_{3}\right)_{2}$.

A mixture of Br-tpy (730 mg; $2.34 \mathrm{mmol})$, TBDMS-BA $(741 \mathrm{mg} ; 2.30 \mathrm{mmol}), \mathrm{Pd}\left(\mathrm{PPh}_{3}\right)_{4}(271 \mathrm{mg}$; $0.24 \mathrm{mmol}), \mathrm{Na}_{2} \mathrm{CO}_{3}(2.50 \mathrm{~g} ; 14.3 \mathrm{mmol})$ in $50 \mathrm{~mL}$ of dioxane and $50 \mathrm{~mL}$ of water was heated at $100{ }^{\circ} \mathrm{C}$ for $72 \mathrm{~h}$. The resultant mixture was extracted with dichloromethane, washed with brine and dried over anhydrous $\mathrm{Na}_{2} \mathrm{SO}_{4}$. The organic solution was filtered and concentrated under reduced pressure. The main product was separated through a basic alumina column eluted with dichloromethane. The concentration gave a yellow solid, which was characterized to be tpyphNOTBDMS (0.911 g; 1.79 mmol). Yield 85\%. m.p: 
212-223 ${ }^{\circ} \mathrm{C} . \mathrm{MS}\left(\mathrm{ESI}^{+}\right) \mathrm{m} / z: 511.29\left(\mathrm{M}+\mathrm{H}^{+}\right) .{ }^{1} \mathrm{H}$ NMR $\left(500 \mathrm{MHz} \mathrm{CDCl}_{3}\right): \delta-0.084(6 \mathrm{H}, \mathrm{br}), 0.93(9 \mathrm{H}, \mathrm{s})$, $1.13(9 \mathrm{H}, \mathrm{s}), 7.36(2 \mathrm{H}, J=8.1 \mathrm{~Hz}, \mathrm{t}), 7.36(2 \mathrm{H}, J=8.6 \mathrm{~Hz}, \mathrm{~d}), 7.77(2 \mathrm{H}, J=8.6 \mathrm{~Hz}, \mathrm{~d}), 7.88(2 \mathrm{H}, J=8.1 \mathrm{~Hz}, \mathrm{t})$ $8.68(2 \mathrm{H}, J=8.1 \mathrm{~Hz}, \mathrm{~d}), 8.73(2 \mathrm{H}, \mathrm{s}), 8.74(2 \mathrm{H}, J=8.1 \mathrm{~Hz}, \mathrm{~d}) .{ }^{13} \mathrm{C} \mathrm{NMR}\left(126 \mathrm{MHz}, \mathrm{CDCl}_{3}\right): \delta 156.34,155.80$, 152.14, 150.20, 149.12, 136.88, 134.56, 126.30, 125.46, 123.79, 121.34, 118.70, 61.44, 26.17, 26.12, 17.96, -4.64. IR (neat, attenuated total reflection (ATR)): 777, 857, 1466, 1061, 2853, 2928, $2957 \mathrm{~cm}^{-1}$.

To a dry tetrahedrofuran (THF) solution $(10 \mathrm{~mL})$ containing tpyphNOTBDMS $(0.911 \mathrm{~g} ; 1.79 \mathrm{mmol})$ $2.5 \mathrm{~mL}(2.5 \mathrm{mmol})$ of tetrabutylammonium fluoride in a THF solution $\left(1 \mathrm{~mol} \mathrm{~L}{ }^{-1}\right)$ was added dropwise at $0{ }^{\circ} \mathrm{C}$ under nitrogen atmosphere. The mixture was stirred for further $1 \mathrm{~h}$ at room temperature. The resultant solution was extracted with dichloromethane after aqueous $\mathrm{NaHCO}_{3}$ was added. The organic layer was dried over anhydrous $\mathrm{Na}_{2} \mathrm{SO}_{4}$ and filtered. After addition of a small amount of hexane, the deprotected product (tpyphNOH) was precipitated as a colorless solid $(0.570 \mathrm{~g}$; $1.43 \mathrm{mmol})$. Yield 85\%. m.p.: 211-212 ${ }^{\circ} \mathrm{C}$. MS $\left(\mathrm{ESI}^{+}\right) \mathrm{m} / z: 397.20\left(\mathrm{M}+\mathrm{H}^{+}\right), 419.17\left(\mathrm{M}+\mathrm{Na}^{+}\right) .{ }^{1} \mathrm{H} \mathrm{NMR}$ $\left(500 \mathrm{MHz} \mathrm{CDCl}_{3}\right): \delta 1.20(9 \mathrm{H}, \mathrm{s}), 7.34(2 \mathrm{H}, J=8.0 \mathrm{~Hz}, \mathrm{t}), 7.38(2 \mathrm{H}, J=8.6 \mathrm{~Hz}, \mathrm{~d}), 7.83(2 \mathrm{H}, J=8.6 \mathrm{~Hz}, \mathrm{t})$ $7.88(2 \mathrm{H}, J=8.0 \mathrm{~Hz}, \mathrm{~d}), 8.66(2 \mathrm{H}, J=8.0 \mathrm{~Hz}, \mathrm{~d}), 8.72(2 \mathrm{H}, \mathrm{s}), 8.73(2 \mathrm{H}, J=8.0 \mathrm{~Hz}, \mathrm{~d}) .{ }^{13} \mathrm{C} \mathrm{NMR}(126 \mathrm{MHz}$, $\left.\mathrm{CDCl}_{3}\right): \delta 156.36,155.72,150.84,149.95,149.16,136.79,135.09,126.56,124.56,123.82,121.22,118.78,60.97$, 26.17. IR (neat, ATR): 730, 788, 1582, 2871, 2978, 3049, 3149, $3743 \mathrm{~cm}^{-1}$.

After the above product $(87 \mathrm{mg} ; 0.22 \mathrm{mmol})$ was dissolved in dichloromethane $(20 \mathrm{~mL})$, freshly prepared $\mathrm{Ag}_{2} \mathrm{O}$ (510 $\mathrm{mg} ; 2.2 \mathrm{mmol}$ ) was added and the resultant mixture was stirred at room temperature for $1 \mathrm{~h}$. The solution portion was filtered and concentrated under reduced pressure. Crystallization from dichloromethane and hexane gave tpyphNO as a red solid $(40 \mathrm{mg} ; 0.11 \mathrm{mmol})$. Yield 46\%. M.p. $154-155^{\circ} \mathrm{C}$. MS $\left(\mathrm{ESI}^{+}\right) \mathrm{m} / z: 396.18\left(\mathrm{M}+\mathrm{H}^{+}\right), 418.16\left(\mathrm{M}+\mathrm{Na}^{+}\right)$. IR (neat, ATR): 660, $778,1193,1250,148,1651,2980 \mathrm{~cm}^{-1}$. ESR $\left(9.4 \mathrm{GHz}\right.$, room temperature in toluene): $a_{\mathrm{N}}=1.165 \mathrm{mT}$, $a_{\mathrm{H}(\text { ortho })}=0.212 \mathrm{mT}(\times 2), a_{\mathrm{H}(\text { meta })}=0.094 \mathrm{mT}(\times 2)$ at $g=2.0065$.

The target complexes were prepared as follows. A methanol solution $(7 \mathrm{~mL})$ involving tpyphNO (40 mg; $0.10 \mathrm{mmol}), \mathrm{CoCl}_{2} \cdot 6 \mathrm{H}_{2} \mathrm{O}(12 \mathrm{mg} ; 0.050 \mathrm{mmol})$ and $\mathrm{LiCF}_{3} \mathrm{SO}_{3}(16 \mathrm{mg} ; 0.10 \mathrm{mmol}$ ) was allowed to stand at $0{ }^{\circ} \mathrm{C}$ under nitrogen atmosphere, to give $\left[\mathrm{Co}(\text { tpyphNO})_{2}\right]\left(\mathrm{CF}_{3} \mathrm{SO}_{3}\right)_{2}$ as a dark red polycrystalline precipitation $\left(27 \mathrm{mg} ; 0.024 \mathrm{mmol}\right.$ ). Yield: $24 \%$. m.p.: $286^{\circ} \mathrm{C}$ (decomp.). The product was subjected to elemental, crystallographic and magnetic analyses without further purification. All data satisfied the formula of the target compound. IR (neat, ATR): 633, 790, 1030, 1136, 1260, 1603, 2935, 2978, $3083 \mathrm{~cm}^{-1}$. Anal. Calcd. for $\mathrm{C}_{52} \mathrm{H}_{46} \mathrm{Co}_{1} \mathrm{~F}_{6} \mathrm{~N}_{8} \mathrm{O}_{8} \mathrm{~S}_{2}: \mathrm{C}, 54.40 ; \mathrm{H}, 4.04 ; \mathrm{N}, 9.76 ; \mathrm{S}, 5.59 \%$. Found: C, $54.34 ; \mathrm{H}, 3.85 ; \mathrm{N}, 9.81 ; \mathrm{S}, 5.69 \%$.

A similar method using tpy in place of tpyphNO gave $\left[\mathrm{Co}(\mathrm{tpy})_{2}\right]\left(\mathrm{CF}_{3} \mathrm{SO}_{3}\right)_{2}$ as orange polycrystals in an $85 \%$ yield. m.p.: $321^{\circ} \mathrm{C}$ (decomp.). The product was subjected to elemental, crystallographic and magnetic analyses without further purification. All data satisfied the formula of the target compound. IR (neat, ATR): 513, 570, 632, 763, 1028, 1126, 1256, 1452, 1600, $3080 \mathrm{~cm}^{-1}$. Anal. Calcd. for $\mathrm{C}_{32} \mathrm{H}_{22} \mathrm{Co}_{1} \mathrm{~N}_{6} \mathrm{O}_{6} \mathrm{~S}_{2}: \mathrm{C}, 46.67 ; \mathrm{H}, 2.69 ; \mathrm{N}, 10.20 ; \mathrm{S}, 7.79 \%$. Found: $\mathrm{C}, 46.29 ; \mathrm{H}, 2.67 ; \mathrm{N}, 10.08 ; \mathrm{S}, 7.37 \%$.

\subsection{Crystallographic Analysis}

X-ray diffraction data of $\left[\mathrm{Co}(\mathrm{L})_{2}\right]\left(\mathrm{CF}_{3} \mathrm{SO}_{3}\right)_{2}(\mathrm{~L}=$ tpyphNO, tpy) were collected on a Rigaku Saturn70 CCD diffractometer with graphite monochromated Mo $\mathrm{K} \alpha$ radiation $(\lambda=0.71073 \AA)$. The structures were directly solved by a heavy-atom method and expanded using Fourier techniques in the CRYSTALSTRUCTURE [30]. Numerical absorption correction was used. Hydrogen atoms were located at calculated positions and their parameters were refined as "riding." The thermal displacement parameters of non-hydrogen atoms were refined anisotropically. Selected crystallographic data are given in Table 1 and selected bond distances and angles are listed in Tables 2 and 3. CCDC numbers 1826042, 1826043, 1826044 and 1826045 contain the crystallographic analysis details for [Co(tpyphNO $\left.)_{2}\right]\left(\mathrm{CF}_{3} \mathrm{SO}_{3}\right)_{2}$ at 90 and $300 \mathrm{~K}$ and $\left[\mathrm{Co}(\text { tpy })_{2}\right]\left(\mathrm{CF}_{3} \mathrm{SO}_{3}\right)_{2}$ at 90 and $400 \mathrm{~K}$, respectively. These data can be obtained free of charge via http:/ / www.ccdc.cam.ac.uk/conts/retrieving.html. 
Table 1. Selected crystallographic parameters of $\left[\mathrm{Co}(\mathrm{L})_{2}\right]\left(\mathrm{CF}_{3} \mathrm{SO}_{3}\right)_{2}(\mathrm{~L}=$ tpyphNO, tpy).

\begin{tabular}{ccccc}
\hline L & tpyphNO & tpyphNO & tpy & tpy \\
\hline$T / K$ & 90 & 300 & 90 & 400 \\
Formula weight & 1148.03 & 1148.03 & 823.61 & 823.61 \\
Crystal system & monoclinic & monoclinic & orthorhombic & orthorhombic \\
Space group & $P 2_{1} / c$ & $P 2_{1} / c$ & $P b c n$ & $P b c n$ \\
$a / \AA$ & $19.6868(14)$ & $20.0956(19)$ & $16.554(4)$ & $16.884(2)$ \\
$b / \AA$ & $16.2129(14)$ & $16.5156(18)$ & $21.145(5)$ & $21.384(3)$ \\
$c / \AA$ & $16.3614(10)$ & $16.4648(14)$ & $9.0805(19)$ & $9.2858(13)$ \\
$\beta /{ }^{\circ}$ & $107.774(4)$ & $108.753(4)$ & 90 & 90 \\
$V / \AA^{3}$ & $4973.0(6)$ & $5174.4(9)$ & $3178.4(12)$ & $3352.7(8)$ \\
$Z$ & 4 & 4 & 4 & 4 \\
$d_{\text {calcd }} / \mathrm{g}^{-\mathrm{cm}^{-3}}$ & 1.533 & 1.474 & 1.721 & 1.632 \\
$\mu($ MoK $\alpha) / \mathrm{mm}^{-1}$ & 0.517 & 0.497 & 0.765 & 0.725 \\
No. of unique reflections & 11373 & 10989 & 3516 & 3569 \\
$R(F)(I>2 \sigma(I))^{\mathrm{a}}$ & 0.0639 & 0.0698 & 0.0567 & 0.0700 \\
$w R\left(F^{2}\right)(\text { all reflections })^{\mathrm{b}}$ & 0.1597 & 0.1869 & 0.1426 & 0.1518 \\
Goodness-of-fit parameter & 1.036 & 1.011 & 0.951 & 1.031 \\
\hline
\end{tabular}

${ }^{\mathrm{a}} R=\Sigma\left[\left|F_{\mathrm{o}}\right|-\left|F_{\mathrm{c}}\right|\right] / \Sigma\left|F_{\mathrm{o}}\right|{ }^{\mathrm{b}} w R=\left[\Sigma w\left(F_{\mathrm{o}}{ }^{2}-{F_{\mathrm{c}}}^{2}\right) / \Sigma w F_{\mathrm{o}}{ }^{4}\right]^{1 / 2}$.

Table 2. Co-N bond distances $(d)$ in $\AA$ for $\left[\mathrm{Co}(\mathrm{L})_{2}\right]\left(\mathrm{CF}_{3} \mathrm{SO}_{3}\right)_{2}(\mathrm{~L}=$ tpyphNO, tpy).

\begin{tabular}{ccccc}
\hline L & tpyphNO & tpyphNO & tpy & tpy \\
\hline$T / \mathrm{K}$ & 90 & 300 & 90 & 400 \\
$d(\mathrm{O} 1-\mathrm{N} 4) / \AA$ & $1.300(4)$ & $1.282(4)$ & - & - \\
$d(\mathrm{O} 2-\mathrm{N} 8) / \AA$ & $1.293(4)$ & $1.279(4)$ & - & - \\
$\mathrm{N}_{\text {central }}$ & & & & $2.024(4)$ \\
$d(\mathrm{Co} 1-\mathrm{N} 2) / \AA$ & $1.877(3)$ & $2.017(3)$ & $1.912(4)$ & $2.023(4)$ \\
$d(\mathrm{Co1}-\mathrm{N} 6 / 4) / \AA$ & $1.941(3)$ & $2.025(3)$ & $1.886(4)$ & 0.12 \\
$d_{\text {central,avg }} / \AA$ & 1.91 & 2.02 & 1.90 & $2.134(3)$ \\
$\Delta d_{\text {central }} / \AA$ & & 0.11 & & $2.120(3)$ \\
$\mathrm{N}_{\text {distal }}$ & & & & - \\
$d(\mathrm{Co1}-\mathrm{N} 1) / \AA$ & $2.011(3)$ & $2.144(3)$ & $2.143(3)$ & - \\
$d(\mathrm{Co} 1-\mathrm{N} 3) / \AA$ & $2.010(3)$ & $2.130(3)$ & $2.017(3)$ & - \\
$d(\mathrm{Co} 1-\mathrm{N} 5) / \AA$ & $2.170(3)$ & $2.154(3)$ & - & 2.13 \\
$d(\mathrm{Co1}-\mathrm{N} 7) / \AA$ & $2.157(3)$ & $2.154(3)$ & 2.08 & 0.05 \\
$d_{\text {distal,avg }} / \AA$ & 2.09 & 2.15 & & \\
$\Delta d_{\text {distal }} / \AA$ & & 0.06 & & \\
\hline
\end{tabular}

Table 3. N-Co-N bond angles $\left(\phi\right.$ in $\left.^{\circ}\right)$ and distortion geometrical parameters $\Sigma$ (in ${ }^{\circ}$ ) and CShM for $\left[\mathrm{Co}(\mathrm{L})_{2}\right]\left(\mathrm{CF}_{3} \mathrm{SO}_{3}\right)_{2}(\mathrm{~L}=$ tpyphNO, tpy).

\begin{tabular}{|c|c|c|c|c|c|}
\hline $\mathbf{L}$ & tpyphNO & tpyphNO & $L^{a}$ & tpy & tpy \\
\hline$T / \mathrm{K}$ & 90 & 300 & $T / K$ & 90 & 400 \\
\hline$\phi(\mathrm{N} 1-\mathrm{Co} 1-\mathrm{N} 2) /^{\circ}$ & $80.99(11)$ & $76.99(11)$ & $\phi(\mathrm{N} 1-\mathrm{Co} 1-\mathrm{N} 2) /^{\circ}$ & $78.93(8)$ & $76.80(8)$ \\
\hline$\phi(\mathrm{N} 1-\mathrm{Co} 1-\mathrm{N} 3) /^{\circ}$ & $161.09(11)$ & $152.95(12)$ & $\phi\left(\mathrm{N} 1-\mathrm{Co} 1-\mathrm{N} 1{ }^{\#}\right) /^{\circ}$ & $157.87(17)$ & $153.59(17)$ \\
\hline$\phi(\mathrm{N} 1-\mathrm{Co} 1-\mathrm{N} 5) /^{\circ}$ & $97.53(10)$ & $100.25(11)$ & $\phi(\mathrm{N} 1-\mathrm{Co} 1-\mathrm{N} 3) /^{\circ}$ & $94.58(12)$ & $96.27(12)$ \\
\hline$\phi(\mathrm{N} 1-\mathrm{Co} 1-\mathrm{N} 6) /^{\circ}$ & $94.64(11)$ & $95.43(11)$ & $\phi\left(\mathrm{N} 1-\mathrm{Co} 1-\mathrm{N} 3{ }^{\#}\right) /^{\circ}$ & $89.07(11)$ & $89.74(12)$ \\
\hline$\phi(\mathrm{N} 1-\mathrm{Co} 1-\mathrm{N} 7) /^{\circ}$ & $89.03(10)$ & 89.93(11) & $\phi(\mathrm{N} 1-\mathrm{Co} 1-\mathrm{N} 4) /^{\circ}$ & $101.07(8)$ & $103.20(8)$ \\
\hline$\phi(\mathrm{N} 2-\mathrm{Co} 1-\mathrm{N} 3) /^{\circ}$ & $80.14(10)$ & $76.20(11)$ & $\phi\left(\mathrm{N} 1{ }^{\#}-\mathrm{Co} 1-\mathrm{N} 4\right) /^{\circ}$ & $101.06(8)$ & $103.21(8)$ \\
\hline$\phi(\mathrm{N} 2-\mathrm{Co} 1-\mathrm{N} 5) /^{\circ}$ & $101.31(11)$ & $103.23(12)$ & $\phi\left(\mathrm{N} 1{ }^{\#}-\mathrm{Co} 1-\mathrm{N} 3\right) /^{\circ}$ & $89.07(11)$ & $89.74(12)$ \\
\hline$\phi(\mathrm{N} 2-\mathrm{Co} 1-\mathrm{N} 6) /^{\circ}$ & $175.55(11)$ & $172.30(11)$ & $\phi\left(\mathrm{N} 1{ }^{\#}-\mathrm{Co} 1-\mathrm{N} 3^{\#}\right) /^{\circ}$ & $94.58(12)$ & $96.27(12)$ \\
\hline$\phi(\mathrm{N} 2-\mathrm{Co} 1-\mathrm{N} 7) /^{\circ}$ & $102.63(11)$ & $104.88(12)$ & $\phi\left(\mathrm{N} 2-\mathrm{Co} 1-\mathrm{N} 1{ }^{\#}\right) /{ }^{\circ}$ & $78.94(8)$ & $76.79(8)$ \\
\hline$\phi(\mathrm{N} 3-\mathrm{Co} 1-\mathrm{N} 5) /^{\circ}$ & $87.43(10)$ & $89.28(11)$ & $\phi(\mathrm{N} 2-\mathrm{Co} 1-\mathrm{N} 3) /^{\circ}$ & $99.53(9)$ & $103.24(9)$ \\
\hline$\phi(\mathrm{N} 3-\mathrm{Co} 1-\mathrm{N} 6) /^{\circ}$ & $104.24(11)$ & $111.44(11)$ & $\phi\left(\mathrm{N} 2-\mathrm{Co} 1-\mathrm{N} 3{ }^{\#}\right) /^{\circ}$ & $99.53(9)$ & $103.24(9)$ \\
\hline$\phi(\mathrm{N} 3-\mathrm{Co} 1-\mathrm{N} 7) /^{\circ}$ & $93.83(10)$ & $93.53(11)$ & $\phi(\mathrm{N} 2-\mathrm{Co} 1-\mathrm{N} 4) /^{\circ}$ & 180.0 & 180.0 \\
\hline$\phi(\mathrm{N} 5-\mathrm{Co} 1-\mathrm{N} 6) /^{\circ}$ & 78.32(11) & $76.55(12)$ & $\phi(\mathrm{N} 3-\mathrm{Co} 1-\mathrm{N} 4) /^{\circ}$ & $80.47(9)$ & $76.76(9)$ \\
\hline$\phi(\mathrm{N} 5-\mathrm{Co} 1-\mathrm{N} 7) /^{\circ}$ & $155.89(10)$ & 151.61(12) & $\phi\left(\mathrm{N} 3-\mathrm{Co} 1-\mathrm{N} 3{ }^{\#}\right) /^{\circ}$ & $160.94(18)$ & $153.52(18)$ \\
\hline$\phi(\mathrm{N} 6-\mathrm{Co} 1-\mathrm{N} 7) /^{\circ}$ & $78.04(11)$ & $76.14(12)$ & $\phi\left(\mathrm{N} 4-\mathrm{Co} 1-\mathrm{N} 3{ }^{\#}\right) /^{\circ}$ & $80.47(9)$ & $76.76(9)$ \\
\hline$\Sigma /{ }^{\circ}$ & 100.2 & 123.7 & $\Sigma /{ }^{\circ}$ & 93.4 & 118.8 \\
\hline CShM (Oh) & 2.824 & 4.282 & CShM (Oh) & 2.484 & 3.672 \\
\hline
\end{tabular}

a Symmetry code for ${ }^{\#}: 1-x,+y, 1 / 2-z$. 


\subsection{Magnetic Study}

Magnetic susceptibilities of $\left[\mathrm{Co}(\mathrm{L})_{2}\right]\left(\mathrm{CF}_{3} \mathrm{SO}_{3}\right)_{2}(\mathrm{~L}=$ tpyphNO, tpy) were measured on a Quantum Design MPMS-XL7 SQUID magnetometer with a static field of $0.5 \mathrm{~T}$. The magnetic responses were corrected with diamagnetic blank data of the sample holder measured separately. The diamagnetic contribution of the sample itself was estimated from Pascal's constants [31].

\section{Results and Discussion}

\subsection{Preparation}

A new ligand tpyphNO was prepared via the Suzuki coupling reaction [32] from commercially available $4^{\prime}$-bromoterpyridine (Br-tpy) and a protected hydroxylaminophenyl boronic acid (TBDMS-BA) [29] (Scheme 2a). Paramagnetic tpyphNO was prepared after the deprotection of the above product with tetrabutylammonium fluoride followed by the oxidation with $\mathrm{Ag}_{2} \mathrm{O}$. The resultant nitroxide was isolated at room temperature under air and characterized as tpyphNO by means of spectroscopic methods including electron spin resonance (ESR) spectroscopy. A target complex [Co(tpyphNO $\left.)_{2}\right]\left(\mathrm{CF}_{3} \mathrm{SO}_{3}\right)_{2}$ was prepared by simply combining methanol solutions of the ligand and $\mathrm{CoCl}_{2}$ in the presence of the counter anion $\mathrm{CF}_{3} \mathrm{SO}_{3}{ }^{-}$(Scheme $2 \mathrm{~b}$ ). As a reference complex, [Co(tpy $\left.)_{2}\right]\left(\mathrm{CF}_{3} \mathrm{SO}_{3}\right)_{2}$ was also prepared in a similar manner, using tpy in place of tpyphNO. The nitroxide-carrying derivative is dark red and the reference is orange at room temperature.

\subsection{Crystal Structures}

The X-ray crystallographic analysis on $\left[\mathrm{Co}(\mathrm{L})_{2}\right]\left(\mathrm{CF}_{3} \mathrm{SO}_{3}\right)_{2}(\mathrm{~L}=$ tpyphNO, tpy) was successful at 90 and 300 or $400 \mathrm{~K}$ (Table 1 and Figure 1). Though the crystal structure of [Co(tpy) $\left.{ }_{2}\right]\left(\mathrm{CF}_{3} \mathrm{SO}_{3}\right)_{2}$ at $120 \mathrm{~K}$ has recently been reported [33], we measured them at 90 and $400 \mathrm{~K}$ to compare the LS and HS structures. The crystal structure of $\left[\mathrm{Co}(\mathrm{tpy})_{2}\right]\left(\mathrm{CF}_{3} \mathrm{SO}_{3}\right)_{2}$ possesses a relatively high symmetry orthorhombic $\mathrm{Pbcn}$, which is kept between 90 and $400 \mathrm{~K}$. A half molecule is crystallographically independent. Compound [ $\left.\mathrm{Co}(\mathrm{tpy})_{2}\right]\left(\mathrm{ClO}_{4}\right)_{2} \cdot 0.5 \mathrm{H}_{2} \mathrm{O}$ is known to crystallize in a tetragonal cell [20] and the relatively low symmetry of $\mathrm{CF}_{3} \mathrm{SO}_{3}{ }^{-}$may cause the different crystal system. On the other hand, the crystal of $\left.[\mathrm{Co} \text { (tpyphNO })_{2}\right]\left(\mathrm{CF}_{3} \mathrm{SO}_{3}\right)_{2}$ belongs to monoclinic $P 2_{1} / c$ and the whole molecule corresponds to an independent unit. The linear spin triad structure is unequivocally characterized. There is no solvent molecule in any crystal.

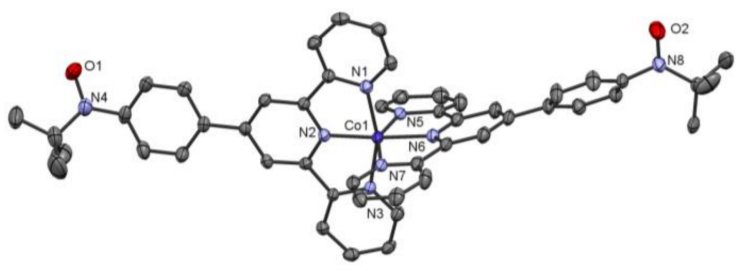

(a)

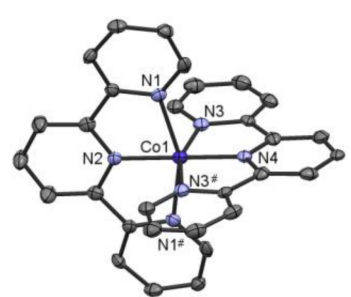

(b)

Figure 1. X-ray crystal structures of $\left[\mathrm{Co}(\mathrm{L})_{2}\right]\left(\mathrm{CF}_{3} \mathrm{SO}_{3}\right)_{2}(\mathrm{~L}=(\mathbf{a})$ tpyphNO; $(\mathbf{b})$ tpy), measured at $90 \mathrm{~K}$. The thermal ellipsoids are drawn at the $50 \%$ probability level. Hydrogen atoms and counter anions are omitted for clarity. The symmetry operation code for ${ }^{\#}$ is $(1-x, y, 1 / 2-z)$ in (b).

The nitroxide group was characterized by the N-O bond lengths (1.300(4) $\AA$ N4-O1 and 1.293(4) $\AA$ for N8-O2 at $90 \mathrm{~K}$ ) in a typical range of aryl tert-butyl nitroxides [34]. The two meridional chelate planes are arranged to be almost perpendicular with the dihedral angle of $94.99(6)^{\circ}$. The long molecular axis is somewhat bent at the metal center, as indicated with the N4...Co1...N8 angle of $159.98(3)^{\circ}$ at $90 \mathrm{~K}$, being considerably smaller than $180^{\circ}$. The 4-phenylpyridine core in each ligand is not coplanar. 
The dihedral angles between the pyridine and adjacent phenyl rings are $10.4(1)$ and $33.8(1)^{\circ}$ at $90 \mathrm{~K}$ with respect to the N2- and N6-pyridine sides, respectively.

The cell volume expansion of the tpy derivative is $4.0 \%$ from 90 to $300 \mathrm{~K}$ and that of the tpyphNO derivative $5.5 \%$ from 90 to $400 \mathrm{~K}$. The considerable volume changes originate in the distance changes between the metal and the coordinated donor atom $(\Delta d)$ accompanying SCO. Usually $\Delta d$ is not so large (0.07-0.11 $\AA$ ) in cobalt(II) SCO complexes as those of the iron(II) complexes $[15,19,20]$, because only one electron is transferred to the antibonding orbital upon SCO [16]. The present $\mathrm{Co}-\mathrm{N}$ bond lengths are completely compatible with those of the previous SCO $\left[\mathrm{Co}(\mathrm{tpy})_{2}\right]^{2+}$ compounds. For example, on the known SCO complex [Co(tpy) $\left.)_{2}\right]\left(\mathrm{BF}_{4}\right)_{2}$, Kilner et al. [19] reported that $d\left(\mathrm{Co}-\mathrm{N}_{\text {central }}\right)$ of the HS state is longer than that of the LS state by $0.12 \AA$ on the average. In our case $\Delta d_{\text {central }}=0.11$ and $0.12 \AA$ for the complexes with $\mathrm{L}=$ tpyphNO and tpy, respectively (Table 2). As for the $\mathrm{Co}-\mathrm{N}_{\text {distal }}$ bond lengths, the HS state possesses longer distances than the LS state by $0.06 \AA$ in $\left[\mathrm{Co}(\mathrm{tpy})_{2}\right]\left(\mathrm{BF}_{4}\right)_{2}$ [19]. The present compounds showed $\Delta d_{\text {distal }}=0.06$ and $0.05 \AA$, respectively. These quite similar geometrical features strongly suggest that the low- and high-temperature structures can be assigned to approximate LS and HS states, respectively. This hypothesis is proven from the magnetic study (see below). The different sensitivity between $\Delta d_{\text {central }}$ and $\Delta d_{\text {distal }}$ is caused by the Jahn-Teller effect due to the LS e ${ }^{1}$ state as well as the steric effect from the rigid ligand.

The HS states are known to favor distorted coordination geometry [35-38]. Among various geometrical parameters, $\Sigma$ and CShM seem to be sensitive and convenient metrics [38]. The $\Sigma$ values [39] were derived from the $\mathrm{N}-\mathrm{Co}-\mathrm{N}$ bond angles (Table 3), according to Equation (1). An ideal octahedron (Oh) possess $\Sigma=0^{\circ}$. By using the SHAPE software [40], the continuous shape measures (CShM) are calculated with respect to an Oh. An ideal Oh returns null. The HS states possess relatively distorted $\mathrm{Oh}$, as expected $\left(4.282\right.$ at $300 \mathrm{~K}$ versus 2.824 at $90 \mathrm{~K}$ for $\left[\mathrm{Co}(\text { tpyphNO})_{2}\right]\left(\mathrm{CF}_{3} \mathrm{SO}_{3}\right)_{2}$ and so on). The bite angle of the five-membered chelate ring seems to be responsible to the difference of $\Sigma$; namely, $\phi$ in the HS state tends to be smaller than that of the LS state $\left(79.37^{\circ}\right.$ at $90 \mathrm{~K}$ versus $76.47^{\circ}$ at $300 \mathrm{~K}$ on the average). Furthermore, the $\phi$ reduction is related to the elongation of the five-membered ring. In short, the $\mathrm{Co}-\mathrm{N}$ distance regulates these distortion parameters.

$$
\Sigma=\sum_{i=1}^{12}\left|\varphi(\angle c i s \mathrm{~N}-\mathrm{Fe}-\mathrm{N})_{i}-90^{\circ}\right|
$$

We have to make a comment on the intermolecular interaction in particular in the crystal of $\left[\mathrm{Co}(\text { tpyphNO})_{2}\right]\left(\mathrm{CF}_{3} \mathrm{SO}_{3}\right)_{2}$. The shortest interatomic distances with respect to the $\mathrm{N}-\mathrm{O}$ groups are 5.205(4) $\AA$ for $\mathrm{O} 4 \ldots \mathrm{O} 2^{\prime}$ and 5.615(4) $\AA$ for $\mathrm{N} 4 \ldots \mathrm{N} 8^{\prime \prime}$ at $90 \mathrm{~K}$ [the symmetry operation codes for ' and " are $(1+x, y, z)$ and $(1+x, 3 / 2-y, 1 / 2+z)$, respectively]. There hardly seems to be any exchange pathway. The tpy portions in the nearest neighboring molecules are arranged parallel with a separation of ca. $3.6 \AA$ (Figure 2). The shortest Co...O(nitroxide) is found as 4.241(3) $\AA$ for $\mathrm{Co} 1 . . \mathrm{OO} 1^{*}$ [the symmetry operation code for ${ }^{*}$ is $(1-x, 1-y, 1-z)$ ]. Two molecules are linked in a head-to-tail manner with two centrosymmetry-related Co1...O1* and Co1*...O1 distances. It is more likely that the intramolecular interaction through $\pi$-conjugation is dominant compared to the intermolecular through-space interaction but relatively short intermolecular distances cannot be neglected completely. In this case, the magnetic properties would be described as the sum of two Co...nitroxide pairs and two nitroxide doublets in every two molecules. This is another interpretation for exchange coupling in $\left[\mathrm{Co}(\text { tpyphNO})_{2}\right]\left(\mathrm{CF}_{3} \mathrm{SO}_{3}\right)_{2}$. However, the motivation of this project never changes, because the cobalt(II) and nitroxide spins are exchange-coupled indeed, whether it works in an intra- or intermolecular fashion. By sharp contrast, such supramolecular contacts are absent from parent $\left[\mathrm{Co}(\text { tpy })_{2}\right]\left(\mathrm{CF}_{3} \mathrm{SO}_{3}\right)_{2}$. 


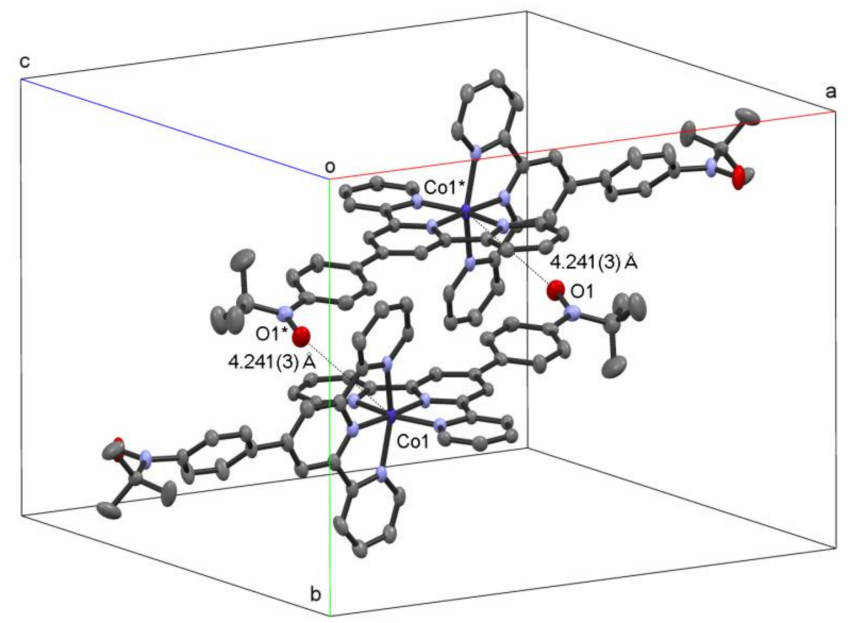

Figure 2. Molecular arrangement in the crystal of $\left[\mathrm{Co}(\text { tpyphNO})_{2}\right]\left(\mathrm{CF}_{3} \mathrm{SO}_{3}\right)_{2}$. Only two molecules are shown. Hydrogen atoms and counter anions are omitted for clarity. Symmetry code for ${ }^{*}: 1-x, 1-y, 1-z$.

\subsection{Magnetic Properties}

The magnetic susceptibilities of polycrystalline specimens of $\left[\mathrm{Co}(\mathrm{L})_{2}\right]\left(\mathrm{CF}_{3} \mathrm{SO}_{3}\right)_{2}$ $(\mathrm{L}=$ tpyphNO, tpy) were measured on a SQUID magnetometer in a temperature range of $1.8-300 \mathrm{~K}$ for the former and $1.8-400 \mathrm{~K}$ for the latter. As Figure 3 shows, the $\chi_{\mathrm{m}} T$ values of $\left[\mathrm{Co}(\mathrm{tpy})_{2}\right]\left(\mathrm{CF}_{3} \mathrm{SO}_{3}\right)_{2}$ were 0.516 and $2.20 \mathrm{~cm}^{3} \mathrm{~K} \mathrm{~mol}^{-1}$ at 90 and $400 \mathrm{~K}$, respectively. From the crystal structure analysis, the spin-state at $90 \mathrm{~K}$ is LS, namely, $S_{\mathrm{Co} 2+}=1 / 2$ and accordingly the Landé factor $g_{\mathrm{Co} 2+, \mathrm{LS}}=2.35$. The spin state at $400 \mathrm{~K}$ is HS, $S_{\mathrm{Co} 2+}=3 / 2$, which leads to $g_{\mathrm{Co2}+, \mathrm{HS}}=2.15$. The latter involves a slight underestimation of $g_{\mathrm{Co} 2+, \mathrm{HS}}$, because the $\chi_{\mathrm{m}} T$ value still has a small positive slope at $400 \mathrm{~K}$. The SCO temperature $T_{1 / 2}$ is defined as the temperature at which equimolar fractions of the HS and LS species are present. The gradual S-shaped curve in $150-400 \mathrm{~K}$ indicates $T_{1 / 2}=\mathrm{ca}$. $260 \mathrm{~K}$ for [Co(tpy $\left.)_{2}\right]\left(\mathrm{CF}_{3} \mathrm{SO}_{3}\right)_{2}$. The $\chi_{\mathrm{m}} T$ value is ideally flat below $100 \mathrm{~K}$. Note that practically no exchange coupling took place, especially illustrated with the constant $\chi_{\mathrm{m}} T$ in a lowest-temperature region.

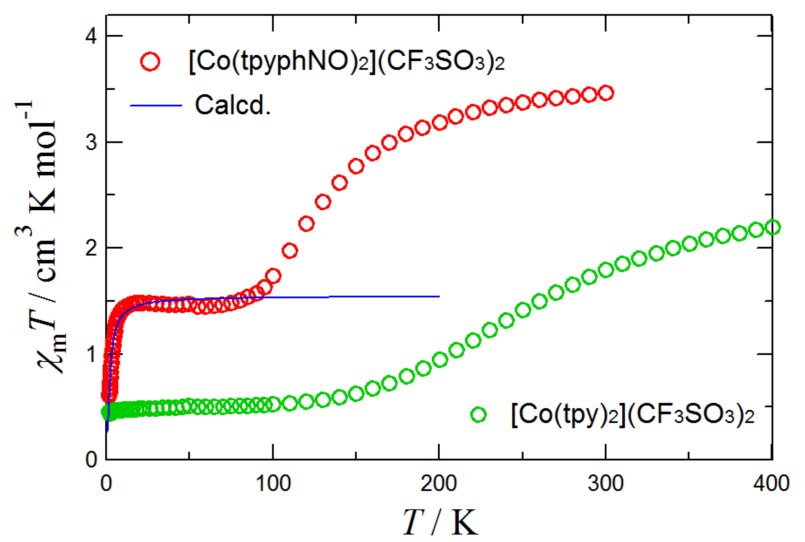

Figure 3. Temperature dependence of $\chi_{\mathrm{m}} T$ for polycrystalline $\left[\mathrm{Co}(\mathrm{L})_{2}\right]\left(\mathrm{CF}_{3} \mathrm{SO}_{3}\right)_{2}(\mathrm{~L}=\mathrm{tpyphNO}$, tpy), measured at 5000 Oe. A solid line represents the calculated curve for a low temperature region. See the text for the equation and optimized parameters.

Referring to the results of $\left[\mathrm{Co}(\mathrm{tpy})_{2}\right]\left(\mathrm{CF}_{3} \mathrm{SO}_{3}\right)_{2}$, we can analogously analyze the data of $\left[\mathrm{Co}(\text { tpyphNO })_{2}\right]\left(\mathrm{CF}_{3} \mathrm{SO}_{3}\right)_{2}$. The $\chi_{\mathrm{m}} T$ versus $T$ profile of $\left[\mathrm{Co}(\mathrm{tpyphNO})_{2}\right]\left(\mathrm{CF}_{3} \mathrm{SO}_{3}\right)_{2}$ is apparently biased from that of $\left[\mathrm{Co}(\mathrm{tpy})_{2}\right]\left(\mathrm{CF}_{3} \mathrm{SO}_{3}\right)_{2}$, by the contribution of two radical spins $\left(0.75 \mathrm{~cm}^{3} \mathrm{~K} \mathrm{~mol}^{-1}\right)$. Another 
cause of this gap is the difference of the $g_{\mathrm{Co} 2+}$ values between the two compounds. The high-temperature $\chi_{\mathrm{m}} T$ value of $\left[\mathrm{Co}(\text { tpyphNO})_{2}\right]\left(\mathrm{CF}_{3} \mathrm{SO}_{3}\right)_{2}$ was $3.47 \mathrm{~cm}^{3} \mathrm{~K} \mathrm{~mol}^{-1}$ at $300 \mathrm{~K}$. On cooling the $\chi_{\mathrm{m}} T$ value decreased to draw an S-shaped profile in $250-100 \mathrm{~K}$ and reached a plateau at ca. $1.45 \mathrm{~cm}^{3} \mathrm{~K} \mathrm{~mol}^{-1}$ around $80 \mathrm{~K}$. On further cooling, the $\chi_{\mathrm{m}} T$ value again decreased to the smallest value $0.607 \mathrm{~cm}^{3} \mathrm{~K} \mathrm{~mol}^{-1}$ at $1.8 \mathrm{~K}$ (the base temperature of the apparatus available). The first drop is ascribable to $\mathrm{Co}^{2+} \mathrm{SCO}$ behavior with $T_{1 / 2}=$ ca. $140 \mathrm{~K}$. The second drop is accordingly assigned to exchange coupling behavior among the LS $\mathrm{CO}^{2+}$ spin and peripheral nitroxide spins.

The spin-Hamiltonian is defined as Equation (2), where $J_{\text {Co-rad }}$ stands for the exchange coupling constant. An approximation is introduced, where the spin centers are symmetrically arrayed in a linear manner and the interaction between the terminals is ignored. The fitting is performed only for analyzing the exchange behavior recorded in a low-spin region. The parameters were optimized according to the van Vleck equation, involving an averaged $g$ value [41,42], giving $g_{\text {avg }}=2.352(9)$ and $2 J_{\text {Co-rad }} / k_{\mathrm{B}}=-3.63(12) \mathrm{K}$. Alternatively, the $g_{\text {rad }}$ and $g_{\mathrm{Co2}+\text {,LS }}$ values can be separated with a more detailed van Vleck equation written as Equation (3) [43]. Assuming that the $g_{\text {rad }}$ value is frozen to 2.006 (from the ESR spectrum of tpyphNO), the optimization gave $g_{\mathrm{Co} 2+, \mathrm{LS}}=2.98(2)$ together with $2 J_{\mathrm{Co}-\mathrm{rad}} / k_{\mathrm{B}}=-3.00(6) \mathrm{K}$. The calculation curve is superposed in Figure 3.

$$
\begin{gathered}
H=-2 J_{\mathrm{Co}-\mathrm{rad}}\left(S_{\mathrm{Co}} \cdot S_{\mathrm{rad} 1}+S_{\mathrm{Co}} \cdot S_{\mathrm{rad} 2}\right) \\
\chi_{\mathrm{m}}=\frac{N_{\mathrm{A}} \mu_{\mathrm{B}}^{2}}{4 k_{\mathrm{B}} T} \frac{10 g_{3 / 2,1}^{2} \exp \left(J_{\mathrm{Co}-\mathrm{rad}} / k_{\mathrm{B}} T\right)+g_{1 / 2,0}^{2}+g_{1 / 2,1}^{2} \exp \left(-2 J_{\mathrm{Co}-\mathrm{rad}} / k_{\mathrm{B}} T\right)}{2 \exp \left(J_{\mathrm{Co}-\mathrm{rad}} / k_{\mathrm{B}} T\right)+1+\exp \left(-2 J_{\mathrm{Co}-\mathrm{rad}} / k_{\mathrm{B}} T\right)}
\end{gathered}
$$

with

$$
\begin{aligned}
& g_{1 / 2,1}=\left(4 g_{\mathrm{rad}}-g_{\mathrm{Co} 2+, \mathrm{LS}}\right) / 3 \\
& g_{3 / 2,1}=\left(2 g_{\mathrm{rad}}+g_{\mathrm{Co} 2+, \mathrm{LS}}\right) / 3 \\
& g_{1 / 2,0}=g_{\mathrm{Co} 2+, \mathrm{LS}}
\end{aligned}
$$

At the ground state, $S_{\text {total }}$ should be $1 / 2$; on the other hand, three paramagnetic spins are present in the almost constant $\chi_{\mathrm{m}} T$ region in ca. $20-80 \mathrm{~K}$. Thanks to the different temperature regions where spin-crossover and exchange coupling effects are operative, the exchange coupling parameter is well resolved to give a precise evaluation. Furthermore, the $\chi_{\mathrm{m}} T$ plateau clearly appeared. In total, $\left[\mathrm{Co}(\text { tpyphNO})_{2}\right]\left(\mathrm{CF}_{3} \mathrm{SO}_{3}\right)_{2}$ can be regarded as a doubly switchable material showing $1 \mu_{\mathrm{B}} \rightleftarrows 3 \mu_{\mathrm{B}} \rightleftarrows 5 \mu_{\mathrm{B}}$ by temperature stimulus.

The $\chi_{\mathrm{m}} T$ versus $T$ profile for $\left[\mathrm{Co}(\mathrm{tpy})_{2}\right]\left(\mathrm{CF}_{3} \mathrm{SO}_{3}\right)_{2}$ shows a very gradual SCO curve, whereas that of $\left[\mathrm{Co}(\text { tpyphNO})_{2}\right]\left(\mathrm{CF}_{3} \mathrm{SO}_{3}\right)_{2}$ displays a relatively abrupt $\mathrm{SCO}$ curve (Figure 3). As described above (Figure 2), there are intermolecular interactions such as short Co...O(nitroxide) distances. The ligands in a neighboring molecule are centrosymmetry-related and planar portions are arranged in parallel with a separation of ca. 3.6 $\AA$. Weak $\pi-\pi$ stacking effects can be found in a dimeric structure as well as in interdimer relation. Owing to the spiro-type structure of the $\left[\mathrm{Co}(\mathrm{tpyphNO})_{2}\right]^{2+}$ core, another parallel stacking motifs spread in the second direction, though the counter anion intervenes. The peripheral substituents like 4-tert-butyl(N-oxy)aminophenyl may serve additional intermolecular interaction, which may contribute cooperativity [44]. Such intermolecular interactions enhance an abrupt character of SCO $[3,44,45]$.

Basically, the $e_{g}$ orbitals with $\sigma$-type symmetry possess no orbital overlap against $\pi$ or $\pi^{*}$-type orbitals of the ligand. This situation has been discussed when the nitroxide radical is directly coordinated to the metal ions $[42,46,47]$ and in the present compound the ligating atom is a pyridine nitrogen atom. The $3 \mathrm{~d}$ electron configuration of $\mathrm{LS} \mathrm{Co}^{2+}$ is $\left(\mathrm{t}_{2 \mathrm{~g}}\right)^{6}\left(\mathrm{e}_{\mathrm{g}}\right)^{1}$ and the magnetic $\mathrm{e}_{\mathrm{g}}$ orbitals might lead to orthogonal geometry between the two magnetic orbitals (Figure 4a,b). However, the orthogonality is very sensitive to the coordination structure and out-of-plane deformation gives rise to loss of ferromagnetic coupling (Figure 4c,d) [14,34,42,48-51]. As the crystallographic analysis revealed, the long molecular axis is considerably bent $\left(159.98(3)^{\circ}\right)$ and the octahedral coordination 
sphere is largely distorted owing to the five-membered chelate ring. Therefore, the orthogonality is ready to breakdown.

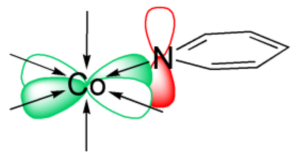

(a)

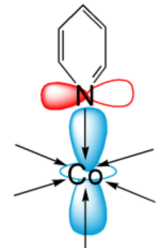

(b)

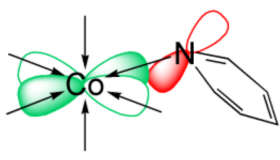

(c)

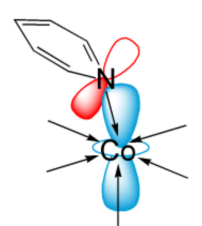

(d)

Figure 4. Schematic drawing of the absence or presence of orbital overlaps. (a,b) Geometries of (a) the Co $3 \mathrm{~d}_{x 2-y 2}$ and $\mathrm{N} 2 \mathrm{p}_{z}$ orbitals or (b) Co $3 \mathrm{~d}_{z 2}$ and $\mathrm{N} 2 \mathrm{p}_{z}$ orbitals with a negligible angular torsion. (c,d) With an appreciable angular torsion.

The magnitude of the exchange coupling is limited to be small $\left(2 J_{\mathrm{Co}-\mathrm{rad}} / k_{\mathrm{B}}=-3.00(6) \mathrm{K}\right)$. It is comparable to several $3 \mathrm{~d}-2 \mathrm{p}$ heterospin exchange coupling across a pyridine ring $[52,53]$ and smaller than the 3d-3d exchange interaction found in the known dinuclear cobalt(II) SCO compound $\left(2 J / h c=11.7 \mathrm{~cm}^{-1}\right)[54]$. There is an intervening organic portion between the $2 \mathrm{p}$ and $3 \mathrm{~d}$ spins in $\left[\mathrm{Co}(\text { tpyphNO})_{2}\right]\left(\mathrm{CF}_{3} \mathrm{SO}_{3}\right)_{2}$. The spin-polarization mechanism is well documented with respect to the 2-, 3- and 4-pyridyl-substituted isomers [52,53]. As shown in Scheme 3, the 1,p-position of the 4-phenylpyridine core plays a role of a magnetic coupler and the ligating nitrogen atom has a positive spin density. As stated above, ferromagnetic coupling would be expected with an orthogonally placed $e_{g}$ spin. However, the spin-polarization is not so effective across a long distance. Moreover, a non-planar biaryl conformation brings about a reduction of the exchange interaction [55-57]. The dihedral angles between the pyridine and adjacent benzene rings are 10.4(1) and $33.8(1)^{\circ}$ in $\left[\mathrm{Co}(\text { tpyphNO})_{2}\right]\left(\mathrm{CF}_{3} \mathrm{SO}_{3}\right)_{2}$. A shorter ligand without a para-phenylene spacer-namely, tert-butyl $2,2^{\prime}: 6^{\prime}, 2^{\prime \prime}$-terpyridin- $4^{\prime}$-yl nitroxide-might be a promising exchange coupler to improve exchange interaction. Its cobalt(II) complexes will be a next target.

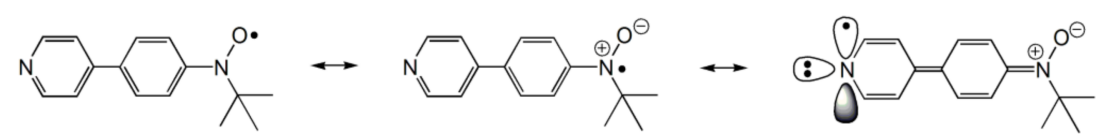

Scheme 3. Canonical structures of tpyphNO.

\section{Conclusions}

The SCO behavior was observed in $\left[\mathrm{Co}(\mathrm{tpy})_{2}\right]\left(\mathrm{CF}_{3} \mathrm{SO}_{3}\right)_{2}$ and $\left[\mathrm{Co}(\mathrm{tpyphNO})_{2}\right]\left(\mathrm{CF}_{3} \mathrm{SO}_{3}\right)_{2}$. The tpy compound showed a gradual SCO in 150-400 K. On the other hand, the tpyphNO derivative exhibited a relatively abrupt $\mathrm{SCO}$ in $100-250 \mathrm{~K}$ together with antiferromagnetic Co-nitroxide exchange coupling with $2 J / k_{\mathrm{B}}=-3.00(6) \mathrm{K}$. The comparison work has proven the coexistence of SCO and exchange coupling in a complex ion $\left[\mathrm{Co}(\text { tpyphNO })_{2}\right]^{2+}$. The $\mathrm{d}-\pi$ magnetic exchange coupling is rationalized with the pyridine $\pi$-conjugation system. Thanks to the different temperature regions where they are operative, the magnetic moment apparently switches double-stepwise as $1 \mu_{\mathrm{B}} \rightleftarrows 3 \mu_{\mathrm{B}} \rightleftarrows 5 \mu_{\mathrm{B}}$ by temperature stimulus. The present work can be regarded as a successful example of development of multifunctional SCO materials including additional magnetic exchange coupling.

Acknowledgments: This work was financially supported from KAKENHI (JSPS/15H03793).

Author Contributions: Akihiro Ondo participated in the preparation, X-ray structural analysis and magnetic study. Takayuki Ishida designed the study and wrote the manuscript.

Conflicts of Interest: The authors declare no conflict of interest. 


\section{References}

1. Gütlich, P.; Goodwin, H.A. (Eds.) Spin Crossover in Transition Metal Compounds I, II, and III; Springer: Berlin, Germany, 2004.

2. Halcrow, M.A. Spin-Crossover Materials: Properties and Applications; John Wiley \& Sons, Ltd.: Oxford, UK, 2013.

3. Kahn, O. Chapter 4, Low-Spin-High-Spin Transition. In Molecular Magnetism; VCH: Weinhein, Germany, 1993.

4. Gentili, D.; Demitri, N.; Schäfer, B.; Liscio, F.; Bergenti, I.; Ruani, G.; Ruben, M.; Cavallini, M. Multi-modal sensing in spin crossover compounds. J. Mater. Chem. C 2015, 3, 7836-7844. [CrossRef]

5. Galyametdinov, Y.; Ksenofontov, V.; Prosvirin, A.; Ovchinnikov, I.; Ivanova, G.; Gutlich, P.; Haase, W. First Example of Coexistence of Thermal Spin Transition and Liquid-Crystal Properties. Angew. Chem. Int. Ed. 2001, 40, 4269-4271. [CrossRef]

6. Oso, Y.; Ishida, T. Spin-crossover transition in a mesophase iron(II) thiocyanate complex chelated with 4-hexadecyl-N-(2-pyridylmethylene)aniline. Chem. Lett. 2009, 38, 604-605. [CrossRef]

7. Oso, Y.; Kanatsuki, D.; Saito, S.; Nogami, T.; Ishida, T. Spin-crossover transition coupled with another solid-solid phase transition for iron(II) thiocyanate complexes chelated with alkylated $\mathrm{N}$-(di-2-pyridylmethylene)anilines. Chem. Lett. 2008, 37, 760-761. [CrossRef]

8. Gass, I.A.; Tewary, S.; Rajaraman, G.; Asadi, M.; Lupton, D.W.; Moubaraki, B.; Chastanet, G.; Létard, J.F.; Murray, K.S. Solvate-dependent spin crossover and exchange in cobalt(II) oxazolidine nitroxide chelates. Inorg. Chem. 2014, 53, 5055-5066. [CrossRef] [PubMed]

9. Gass, I.A.; Tewary, S.; Nafady, A.; Chilton, N.F.; Gartshore, C.J.; Asadi, M.; Lupton, D.W.; Moubaraki, B.; Bond, A.M.; Boas, J.F.; et al. Observation of ferromagnetic exchange, spin crossover, reductively induced oxidation, and field-induced slow magnetic relaxation in monomeric cobalt nitroxides. Inorg. Chem. 2013, 52, 7557-7572. [CrossRef] [PubMed]

10. Kitazawa, T.; Gomi, Y.; Takahashi, M.; Takeda, M.; Enomoto, M.; Miyazaki, A.; Enoki, T. Spin-crossover behaviour of the coordination polymer $\mathrm{Fe}^{\mathrm{II}}\left(\mathrm{C}_{5} \mathrm{H}_{5} \mathrm{~N}\right)_{2} \mathrm{Ni}^{\mathrm{II}}(\mathrm{CN})_{4}$. J. Mater. Chem. 1996, 6, 119-121. [CrossRef]

11. Letard, J.-F.; Guionneau, P.; Nguyen, O.; Costa, J.S.; Marcen, S.; Chastanet, G.; Marchivie, M.; Goux-Capes, L. A guideline to the design of molecular-based materials with long-lived photomagnetic lifetimes. Chem. Eur. J. 2005, 11, 4582-4589. [CrossRef] [PubMed]

12. Mochida, N.; Kimura, A.; Ishida, T. Spin-Crossover Hysteresis of $\left[\mathrm{Fe}^{\mathrm{II}}\left(\mathrm{L}_{\mathrm{H}}{ }^{\mathrm{iPr}}\right)_{2}(\mathrm{NCS})_{2}\right]\left(\mathrm{L}_{\mathrm{H}}{ }^{\mathrm{iPr}}={ }^{\mathrm{N}-2-}\right.$ Pyridylmethylene-4-isopropylaniline Accompanied by Isopropyl Conformation Isomerism. Magnetochemistry 2015, 1, 17-27. [CrossRef]

13. Yamasaki, M.; Ishida, T. Heating-rate dependence of spin-crossover hysteresis observed in an iron(II) complex having tris(2-pyridyl)methanol. J. Mater. Chem. C 2015, 3, 7784-7787. [CrossRef]

14. Homma, Y.; Ishida, T. A New $S=0 \rightleftarrows S=2$ "Spin-crossover" Scenario Found in a Nickel(II) Bis(nitroxide) System. Chem. Mater. 2018, 30, 1835-1838. [CrossRef]

15. Hayami, S.; Komatsu, Y.; Shimizu, T.; Kamihata, H.; Lee, Y.H. Spin-crossover in cobalt(II) compounds containing terpyridine and its derivatives. Coord. Chem. Rev. 2011, 255, 1981-1990. [CrossRef]

16. Krivokapic, I.; Zerara, M.; Daku, M.L.; Vargas, A.; Enachescu, C.; Ambrus, C.; Tregenna-Piggott, P.; Amstutz, N.; Krausz, E.; Hauser, A. Spin-crossover in cobalt(II) imine complexes. Coord. Chem. Rev. 2007, 251, 364-378. [CrossRef]

17. Murray, K.S. Advances in Polynuclear Iron(II), Iron(III) and Cobalt(II) Spin-Crossover Compounds. Eur. J. Inorg. Chem. 2008, 3101-3121. [CrossRef]

18. Brooker, S. Spin crossover with thermal hysteresis: Practicalities and lessons learnt. Chem. Soc. Rev. 2015, 44, 2880-2892. [CrossRef] [PubMed]

19. Kilner, C.A.; Halcrow, M.A. An unusual discontinuity in the thermal spin transition in $\left[\mathrm{Co}(\operatorname{terpy})_{2}\right]\left[\mathrm{BF}_{4}\right]_{2}$. Dalton Trans. 2010, 39, 9008-9012. [CrossRef] [PubMed]

20. Oshio, H.; Spiering, H.; Ksenofontov, V.; Renz, F.; Gütlich, P. Electronic Relaxation Phenomena Following ${ }^{57} \mathrm{Co}(\mathrm{EC}){ }^{57} \mathrm{Fe}$ Nuclear Decay in $\left[\mathrm{Mn}^{\mathrm{II}}(\text { terpy })_{2}\right]\left(\mathrm{ClO}_{4}\right)_{2} \cdot 1 / 2 \mathrm{H}_{2} \mathrm{O}$ and in the Spin Crossover Complexes $\left[\mathrm{Co}^{\mathrm{II}}(\text { terpy })_{2}\right] \mathrm{X}_{2} \cdot \mathrm{nH}_{2} \mathrm{O}\left(\mathrm{X}=\mathrm{Cl}\right.$ and $\left.\mathrm{ClO}_{4}\right)$ : A Mössbauer Emission Spectroscopic Study. Inorg. Chem. 2001, 40, 1143-1150. [CrossRef] [PubMed]

21. Aroua, S.; Todorova, T.K.; Hommes, P.; Chamoreau, L.M.; Reissig, H.U.; Mougel, V.; Fontecave, M. Synthesis, Characterization, and DFT Analysis of Bis-Terpyridyl-Based Molecular Cobalt Complexes. Inorg. Chem. 2017, 56, 5930-5940. [CrossRef] [PubMed] 
22. Enachescu, C.; Krivokapic, I.; Zerara, M.; Real, J.A.; Amstutz, N.; Hauser, A. Optical investigation of spin-crossover in cobalt(II) bis-terpy complexes. Inorg. Chim. Acta 2007, 360, 3945-3950. [CrossRef]

23. Adams, D.M.; Hendrickson, D.N. Pulsed laser photolysis and thermodynamics studies of intramolecular electron transfer in valence tautomeric cobalt o-quinone complexes. J. Am. Chem. Soc. 1996, 118, 11515-11528. [CrossRef]

24. Pierpont, C.G. Studies on charge distribution and valence tautomerism in transition metal complexes of catecholate and semiquinonate ligands. Coord. Chem. Rev. 2001, 216, 99-125. [CrossRef]

25. Escax, V.; Bleuzen, A.; Cartier dit Moulin, C.; Villain, F.; Goujon, A.; Varret, F.; Verdaguer, M. Photoinduced Ferrimagnetic Systems in Prussian Blue Analogues $\mathrm{CI}_{x} \mathrm{Co}_{4}\left[\mathrm{Fe}(\mathrm{CN})_{6}\right]_{\mathrm{y}}(\mathrm{CI}=$ Alkali Cation). 3. Control of the Photo-and Thermally Induced Electron Transfer by the $\left[\mathrm{Fe}(\mathrm{CN})_{6}\right]$ Vacancies in Cesium Derivatives. J. Am. Chem. Soc. 2001, 123, 12536-12543. [CrossRef] [PubMed]

26. Sato, O.; Cui, A.; Matsuda, R.; Tao, J.; Hayami, S. Photo-induced valence tautomerism in Co complexes. Acc. Chem. Res. 2007, 40, 361-369. [CrossRef] [PubMed]

27. Calder, A.; Forrester, A.R. Nitroxide radicals. Part VI. Stability of meta-and para-alkyl substituted phenyl-t-butylnitroxides. J. Chem. Soc. C 1969, 1459-1464. [CrossRef]

28. Murata, H.; Lahti, P.M.; Aboaku, S. Molecular recognition in a heteromolecular radical pair system with complementary multipoint hydrogen-bonding. Chem. Commun. 2008, 3441-3443. [CrossRef] [PubMed]

29. Lahti, P.M.; Liao, Y.; Julier, M.; Palacio, F. s-Triazine as an exchange linker in organic high-spin molecules. Synth. Met. 2001, 122, 485-493. [CrossRef]

30. CrystalStructure, Version 4.2.1; Rigaku/MSC: The Woodlands, TX, USA, 2015.

31. Kahn, O. Chapter 1.2, Diamagnetic and Paramagnetic Susceptibilities. In Molecular Magnetism; VCH: Weinhein, Germany, 1993.

32. Suzuki, A. Cross-coupling reactions of organoboranes: An easy way to construct C-C bonds (Nobel lecture). Angew. Chem. Int. Ed. 2011, 50, 6722-6737. [CrossRef] [PubMed]

33. Pavlov, A.A.; Denisov, G.L.; Kiskin, M.A.; Nelyubina, Y.V.; Novikov, V.V. Probing Spin Crossover in a Solution by Paramagnetic NMR Spectroscopy. Inorg. Chem. 2017, 56, 14759-14762. [CrossRef] [PubMed]

34. Okazawa, A.; Nagaichi, Y.; Nogami, T.; Ishida, T. Magneto-structure relationship in copper(II) and nickel(II) complexes chelated with stable tert-butyl 5-phenyl-2-pyridyl nitroxide and related radicals. Inorg. Chem. 2008, 47, 8859-8868. [CrossRef] [PubMed]

35. Wu, S.Q.; Wang, Y.T.; Cui, A.L.; Kou, H.Z. Toward Higher Nuclearity: Tetranuclear Cobalt(II) Metallogrid Exhibiting Spin Crossover. Inorg. Chem. 2014, 53, 2613-2618. [CrossRef] [PubMed]

36. Tiwary, S.K.; Vasudevan, S. Void geometry driven spin crossover in zeolite-encapsulated cobalt tris(bipyridyl) complex ion. Inorg. Chem. 1998, 37, 5239-5246. [CrossRef]

37. Halcrow, M.A. Structure: Function relationships in molecular spin-crossover complexes. Chem. Soc. Rev. 2011, 40, 4119-4142. [CrossRef] [PubMed]

38. Kimura, A.; Ishida, T. Pybox-Iron(II) Spin-Crossover Complexes with Substituent Effects from the 4-Position of the Pyridine Ring (Pybox = 2,6-Bis(oxazolin-2-yl)pyridine). Inorganics 2017, 5, 52.

39. Guionneau, P.; Marchivie, M.; Bravic, G.; Létard, J.-F.; Chasseau, D. Structural Aspects of Spin Crossover. Example of the $\left[\mathrm{Fe}^{\mathrm{II}} \mathrm{L}_{\mathrm{n}}(\mathrm{NCS})_{2}\right]$ Complexes. Top. Curr. Chem. 2004, 234, 97-128.

40. Lluncll, M.; Casanova, D.; Circra, J.; Bofill, J.M.; Alcmany, P.; Alvarez, S.; Pinsky, M.; Avnir, D. SHAPE, v2.1; University of Barcelona: Barcelona, Spain; The Hebrew University of Jerusalem: Jerusalem, Israel, 2005.

41. Gruber, S.J.; Harris, C.M.; Sinn, E. Metal complexes as ligands. VI. Antiferromagnetic interactions in trinuclear complexes containing similar and dissimilar metals. J. Chem. Phys. 1968, 49, 2183-2191. [CrossRef]

42. Okazawa, A.; Nogami, T.; Ishida, T. tert-Butyl 2-Pyridyl Nitroxide Available as a Paramagnetic Chelate Ligand for Strongly Exchange-Coupled Metal-Radical Compounds. Chem. Mater. 2007, 19, 2733-2735. [CrossRef]

43. Kahn, O. Chapter 10, Trinuclear Compounds and Compounds of Higher Nuclearity. In Molecular Magnetism; VCH: Weinhein, Germany, 1993.

44. Boca, R. Theoretical Foundations of Molecular Magnetism: Current Methods in Inorganic Chemistry; Elsevier: Amsterdam, The Netherlands, 1999; Volume 1.

45. Sorai, M.; Seki, S. Phonon Coupled Cooperative Low-Spin ${ }^{1} \mathrm{~A}_{1}$ High-Spin ${ }^{5} \mathrm{~T}_{2}$ transition in $\left[\mathrm{Fe}(\mathrm{phen})_{2}(\mathrm{NCS})_{2}\right]$ and [Fe(phen $)_{2}(\mathrm{NCSe})_{2}$ ] Crystals. J. Phys. Chem. Solids 1974, 35, 555-570. [CrossRef] 
46. Luneau, D.; Rey, P.; Laugier, J.; Belorizky, E.; Conge, A. Ferromagnetic Behavior of Nickel(II)-Imino Nitroxide Derivatives. Inorg. Chem. 1992, 31, 3578-3584. [CrossRef]

47. Ondo, A.; Ishida, T. Structures and magnetic properties of transition metal complexes involving 2, 2'-bipyridin-6-yl nitroxide. AIP Conf. Proc. 2017, 1807, 020023.

48. Okazawa, A.; Nogami, T.; Ishida, T. Strong intramolecular ferromagnetic couplings in nickel(II) and copper(II) complexes chelated with tert-butyl 5-methoxy-2-pyridyl nitroxide. Polyhedron 2009, 28, 1917-1921. [CrossRef]

49. Okazawa, A. Magneto-Structural Relationship on Strong Exchange Interactions between Chelating Nitroxide Radical and Transition-Metal Spins. IOP Conf. Ser. Mater. Sci. Eng. 2017, 202, 012002. [CrossRef]

50. Okazawa, A.; Hashizume, D.; Ishida, T. Ferro-and antiferromagnetic coupling switch accompanied by twist deformation around the copper(II) and nitroxide coordination bond. J. Am. Chem. Soc. 2010, 132, 11516-11524. [CrossRef] [PubMed]

51. Okazawa, A.; Ishida, T. Spin-Transition-Like Behavior on One Side in a Nitroxide-Copper(II)-Nitroxide Triad System. Inorg. Chem. 2010, 49, 10144-10147. [CrossRef] [PubMed]

52. Shimada, T.; Ishida, T.; Nogami, T. Magnetic properties of transition metal complexes with 2, 2'-bipyridin-5-yl t-butyl nitroxide. Polyhedron 2005, 24, 2593-2598. [CrossRef]

53. Kumada, H.; Sakane, A.; Koga, N.; Iwamura, H. Through-bond magnetic interaction between the $2 \mathrm{p}$ spin of the aminoxyl radical and the $3 \mathrm{~d}$ spin of the metal ions in the complexes of bis(hexafluoroacetylacetonato)manganese(II) and -copper(II) with 4-(N-tert-butyl-N-oxylamino)-2,2'-bipyridine. J. Chem. Soc. Dalton Trans. 2000, 911-914. [CrossRef]

54. Brooker, S.; Plieger, P.G.; Moubaraki, B.; Murray, K.S. [Co $\left.{ }_{2}{ }_{2} \mathrm{~L}(\mathrm{NCS})_{2}(\mathrm{SCN})_{2}\right]$ : The First Cobalt Complex to Exhibit Both Exchange Coupling and Spin Crossover Effects. Angew. Chem. Int. Ed. 1999, 38, 408-410. [CrossRef]

55. Damrauer, N.H.; Boussie, T.R.; Devenney, M.; McCusker, J.K. Effects of intraligand electron delocalization, steric tuning, and excited-state vibronic coupling on the photophysics of aryl-substituted bipyridyl complexes of Ru(II). J. Am. Chem. Soc. 1997, 119, 8253-8268. [CrossRef]

56. Nishizawa, S.; Hasegawa, J.Y.; Matsuda, K. Theoretical investigation of the dependence of exchange interaction on dihedral angle between two aromatic rings in a wire unit. Chem. Lett. 2013, 43, 530-532. [CrossRef]

57. Ravat, P.; Baumgarten, M. “Tschitschibabin type biradicals": Benzenoid or quinoid? Phys. Chem. Chem. Phys. 2015, 17, 983-991. [CrossRef] [PubMed] 